\title{
FACTORS INFLUENCING GREEN ROOF DEVELOPMENT IN RECIFE, BRAZIL
}

\author{
Ana Letícia B. F. LEMOS ${ }^{1}$, Linda KAUŠKALE ${ }^{2}$ \\ ${ }^{1}$ Federal Rural University of Pernambuco, Brazil \\ ${ }^{2}$ Riga Technical University, Latvia \\ Corresponding author e-mail: \\ analeticialemos15@gmail.com
}

\begin{abstract}
In Recife, Brazil, population growth and development of buildings in the Central region generated an increase of almost $70 \%$ in the last 20 years due to the large number of companies that have been allocated in the city generating an increase in the local economy and the significant population increase, creating huge heat islands. Due to this, a new technology has been implemented in the real estate market: The green roofs, a technology of sustainable coverage that allows implantation of soil and vegetation in a waterproofed layer on the constructions. The benefits of this technology include the reduction of temperature by consumption of $\mathrm{CO}_{2}$, a good option for storing rainwater for nonpotable purposes and the possibility of growing organic vegetable gardens for own consumption or sale, generating a new form of income. The aim of the research is to evaluate the factors that interfere with the introduction of sustainable coverage technology of green roofs in the present siting of the city. In this article, the factors that interfere with the implementation of green roof technology in the present siting of the city will be evaluated, focusing on the analysis of internal and external influencing factor. Comparison, historical, statistical data analysis, induction, logical access methods and external and internal influencing factor analysis were used in the research besides the practical development of arguments and graphical representation of research results.
\end{abstract}

Keywords: Brazil, construction, environment, green buildings, green roofs, heat islands, real estate market, Recife, sustainability

\section{INTRODUCTION}

The growth of the world population occurred in a heterogeneous way, so that half the world population now resides in large urban centers. In Brazil alone, almost $80 \%$ of the population live in large cities, conditioned by the mass of disadvantaged people who move to the cities for searching for better job offers and consequently improving the quality of life. These people do not have the resources to support their own land costs, so the big urban centers turn out to be more supportive. This results in high population density with pollution problems and, in the case of Recife, which is a tropical city with high rainfall, problems with heat islands that develop high temperatures, as well as flood problems due to large amounts of rainfall in the region which cannot be managed because of the city's inefficient drainage system. 
The aim of the research is to evaluate the factors that interfere with the implementation of sustainable coverage technology of green roofs in the present siting of the city. Comparison, historical, statistical data analysis, induction, logical access methods and external and internal influencing factor analysis were used in the research besides the practical development of arguments and analysis of graphical representation of research results.

One technology that can partially solve the above-mentioned problems and is becoming increasingly popular among economically developed cities seeking for the balance between the construction market and the preservation of the environment are green roofs consisting of artificial roofing systems for buildings, housing or even support structures, in which various types of materials are applied, allowing the correct functioning of the roof and taking advantage of its architecture, aesthetics and environment. It is the system that is well known for its benefits, including thermal insulation and water storage. Both factors will be very beneficial for the city of Recife, they may help minimize the incidence of solar rays on the roofs and consequently decrease the interior temperature of the buildings. In addition, they may help reduce flooding in the city by decreasing the load on its drainage system ensuring the storage of non-potable water.

The objective of this project is to analyze through the external and internal influencing factor analysis the arguments that support the implementation of this coverage system, the economic implications that the introduction of green roofs may have for the construction market within the Brazilian national economy and the economy of the metropolitan region of Recife, considering all the points of interest like price, competition and jurisdiction, to make forecasts on the implementation of this technology and the reaction of the real estate market.

\section{THEORETICAL ASPECT OVERVIEW}

Since the end of the nineteenth century, Germany has pioneered major advances in plant cover technologies, providing financial and fiscal incentives for flood control and energy efficiency, with hundreds of millions of Euros invested each year in green roofs, covering about $15 \%$ of German roofs. This tendency has been spreading in Europe, especially in such countries as Austria, Hungary, Scandinavia, Switzerland and the United Kingdom, reaching an impressive mark of about 3.3 million $\mathrm{m}^{2}$ of green roofs installed per year. Meanwhile, Brazil alone stands at only 200 thousand square meters a year, but this figure is growing over time (Rocha, 2016).

In the initial stage of the analysis, it is necessary to characterize briefly the current situation in the country that consequently affects the particular city. Recife is a metropolitan city, one of the main economies of the northeast of the country, situated on the coast of the South Atlantic Ocean with a territorial area of approximately $218 \mathrm{~km}^{2}$, a tourist destination throughout the year and the target for large business centers with large investment. The legislation of Recife is being defined by Recife Municipal Law (2015). According to the IBGE in partnership with the State Statistical Agencies, Recife recorded nominal GDP (Gross Domestic Product) of 50.688 billion Real and nominal GDP per capita of 31,513.07 Real in 
2014. About two-thirds of GDP comes from trade and services. In the same year, the Recife Urban Concentration reached a nominal GDP of 97.589 billion Real, the highest among urban concentrations of the North-Northeast.

After 2014, the Brazilian economic crisis caused by political problems abruptly affected the situation in the civil construction market, and consequently Recife, as it is the city dependent on the large growth in this area. The number of new constructions declined considerably in the following years. Devastated. According to CBIC (Brazilian Chamber of Construction Industry), Investments, essential to the development of any economy, especially emerging economies, fell by $14.1 \%$ in 2015, public works had to be stopped and corruption scandals affected several private companies, which had to reduce spending and reduce the number of buildings.

With the intention of reducing heat islands and preserving local biodiversity, the Municipal Law 18.112 was approved in Recife. The measure is applied to any construction of buildings with more than four floors or units with covered area above $400 \mathrm{~m}^{2}$, buildings need to be covered with grass, greenery, shrubs or small trees, preferably of species native to the area. According to the project, it is still necessary to install rainwater catchment and delay systems in all new residential, commercial or service properties with a land area of more than 500 square meters and that have $25 \%$ of the waterproofed terrain. In this way, there is the advantage of reusing the water for various uses, such as maintenance, cleaning and watering of plants. In addition, the system should aid in the drainage of the city, as the water delay tools release the resource gradually in the galleries, avoiding the overload.

Modern green roofs were first installed in Germany in the $20^{\text {th }}$ century with an intent to solve the harmful physical effects of solar radiation on the structure of roof (Köhler, 2003). Since then, German cities have set up incentive programs to promote the deployment of green roofs and improve environmental standards across the country. Currently, building law requires green roof construction in many urban centers as a way to combat pollution (Köhler \& Keeley, 2005).

The green roof is a technique considered new in the civil engineering market, it is constructed from a soil media, followed by a drainage layer and a high quality waterproof membrane to protect a building structure. The basic components of roof technology from the concrete slab interface are: an impermeable root repellent membrane, a drainage layer, a filter membrane (geotextile), culture medium and a layer of vegetation (Palla et al., 2011).

According to Fioretti et al. (2010), the techniques used on the green roofs are usually categorized into three different classes: intensive, semi-intensive and extensive. The authors specify that the differences are seen in the thickness of the stratigraphy, the expected use of the roof and maintenance costs. The authors also mention that intensive green roofs are thick and therefore are heavy systems used for structures that withstand larger loads that require frequent maintenance. At the same time, extensive green roofs are lightweight systems that do not require maintenance and cannot be routed to any structure, while semi-intensive green roofs are mid-level systems.

Green roofs are the system known in the construction market for its benefits, such as ability to reflect between $20 \%$ and $30 \%$ of solar radiation and to absorb up 
to $60 \%$ of it through photosynthesis, energy efficiency of green roofs is associated with a reduction of heat flow in the range of $70 \%-90 \%$ in summer and $10 \%-30 \%$ in winter (Weng et al., 2004). Another benefit is energy reduction, since the installation of green roofs can cause a decrease of $25 \%-80 \%$ in the use of air conditioning because of the decrease in temperature (Wong et al., 2003). Green roofs can have a huge effect on acoustic insulation, since they reduce noise caused by the effect of rainfall, because of the additional layers of mass with low stiffness causing a damping effect (Asdrubali et al., 2012). In addition to these benefits, much research on water storage, including in older buildings, has predicted the emergence of this new load in the structures. The non-potable water storage technology provided by the green roofs is not only a benefit to the consumer but also an efficient way to minimize flooding caused by rainwater because of the malfunction of the city's drainage system. (Garcia-Estringana et al., 2010).

In the current market, green roofs have been reevaluated due to the adoption of layers of bitumen in their structures. That is, a water resistance layer is usually accused of not being an ecological material. According to the study conducted by Bianchini and Hewage, a comparison of the life cycle analysis between two polymeric materials used in green roofs, such as recycled low density polyethylene (LDPE) and low density non-recycled polyethylene (LDPE) was carried out. The results are that the use of the recycled material leads to 2.8 times less toxic substances released into the air. And the toxic concentration of nitrogen dioxide $\left(\mathrm{NO}_{2}\right)$, sulfur dioxide $\left(\mathrm{SO}_{2}\right)$, ozone $\left(\mathrm{O}_{3}\right)$ and particulate matter (PM10) derived from the use of non-recycled LDPE are comparatively larger than the indicators of the recycled type.

The evaluation of cost benefit depends on several factors since the price of the installation depends on the costs of labor and equipment, materials used, type of construction, vegetation adopted, the type of green roof system used and its dependence on maintenance, which varies greatly with the region's climate, and this requires a high initial investment value to obtain the quality product (Carter \& Jackson, 2007). The consumer market for green roofing technology is usually quite broad, including private construction companies, contractors or even households who are willing to hire a company to do the installation. In the case of Recife, as the law should be applied to all constructions erected in the city, this market should extend to constructions built by the public sector and constructions developed for industrial purposes.

The external factor analysis helps organize contributors affecting the subject, considering political, economic, social, technological, environmental and legal factors. It may reflect the advantages and disadvantages within each topic. Factors and impacts caused by installation of green roofs within external factor analysis are shown in Table 1. 
Table 1. Factors and Impacts Caused by Green Roofs within External Factor Analysis [table compiled by the authors]

\begin{tabular}{|c|c|}
\hline Factors & Impacts \\
\hline $\begin{array}{l}\text { Political } \\
\text { Factors }\end{array}$ & $\begin{array}{l}\text { - The green roofs, through public policies that promote environmental } \\
\text { preservation, contribute to instill a governmental change in social behavior, } \\
\text { which can be stimulated through the granting of fiscal and credit subsidies, } \\
\text { among others (Amado, 2011). } \\
\text { - Municipal Law } 18.112 \text {. requires that any new buildings with more than four } \\
\text { floors or units with covered area above } 400 \text { square meters need to be } \\
\text { covered with grass, greenery, shrubs or small trees, preferably of species } \\
\text { native to the area. }\end{array}$ \\
\hline $\begin{array}{l}\text { Economic } \\
\text { Factors }\end{array}$ & $\begin{array}{l}\text { - Maintenance of the green roof should be done only once or twice a year, } \\
\text { depending on the type of the roof. Intensive green roofs require more } \\
\text { maintenance and service during the year, since the soil is } 150 \mathrm{~mm} \text { to } \\
300 \mathrm{~mm} \text { and may have several species of plants and trees due to the high } \\
\text { variety of vegetation in the region. } \\
\text { - Residents who have maintained a minimum green area of } 30 \% \text { of the total } \\
\text { area of the property, using devices such as the green roof and others, so as } \\
\text { to allow their permeabilization to absorb rainwater can obtain partial } \\
\text { exemption of } 10 \% \text { (ten percent) of the IPTU (Urban Land and Building Tax). } \\
\text { - Currently there are a limited number of companies and professionals trained } \\
\text { to maintain green roofs, and an even smaller number of component } \\
\text { suppliers for their construction. The small number of skilled professionals } \\
\text { would certainly inflate service costs. } \\
\text { The instantaneous increase in the volume of work can generate delays in } \\
\text { civil construction works and the intense demand can bring problems in the } \\
\text { medium and short term with the provision of installation services without } \\
\text { adequately trained manpower. }\end{array}$ \\
\hline Social Factors & $\begin{array}{l}\text { - Green hedges present a possibility of income generation, with the } \\
\text { cultivation of ornamental plants, medicinal and domestic seasonings. This } \\
\text { is already a reality in some countries of the world and makes it possible to } \\
\text { professionalize and employ people if the products are marketed, providing } \\
\text { a new socioeconomic segment. } \\
\text { - Poorly installed green roofs can have negative consequences for public } \\
\text { health as infiltrations that can lead to cardiorespiratory problems caused by } \\
\text { the proliferation of fungi in the environments. }\end{array}$ \\
\hline $\begin{array}{l}\text { Technological } \\
\text { Factors }\end{array}$ & $\begin{array}{l}\text { - According to Sharman (2014), the City of Sidney website in the so-called } \\
\text { "Green Roofs and Walls Policy Implementation Plan" lays out the inductive } \\
\text { policies for stimulating the installation of roofs and green walls offering } \\
\text { intangible incentives such as research, awards, specific programs and } \\
\text { technical guidance. } \\
\text { - The study on green roofs can develop better and cheaper technologies for } \\
\text { waterproofing and storing rainwater. } \\
\text { - Green roofs have been considered because of the great potential related to } \\
\text { sound absorption and noise isolation, being a great example of acoustic } \\
\text { insulation technology (Van Renterghem \& Botteldooren, 2011). }\end{array}$ \\
\hline Legal Factors & $\begin{array}{l}\text { - Up to the present time there are no technical standards for the construction } \\
\text { of green roofs, which does not provide adequate guidance to professionals } \\
\text { and limits consumer protection. A desirable standard can also provide for } \\
\text { safe accessibility in roof maintenance, which avoids accidents. } \\
\text { - Unfortunately, as green roofs are relatively recent in the construction field, } \\
\text { there are not many consumer law standards that set out some limitations or } \\
\text { that regularly standards that ensure that companies provide quality service. }\end{array}$ \\
\hline
\end{tabular}


Trends and regional advantages that favor installation of green roofs in Recife, Brazil, are analyzed in the second part.

\section{TRENDS AND REGIONAL ADVANTAGES THAT FAVOR INSTALLATION OF GREEN ROOFS IN RECIFE}

\subsection{Evolution of GDP}

Before predicting the success or failure of any market line of a company that wishes to enter the Brazilian real estate market without knowing the return on investment, it is necessary to analyze the Brazilian economic situation, which had problems in the years 2014, 2015 and 2016 because of a series of factors that, in addition to the fiscal adjustment and the rise in interest rates, also include low confidence of entrepreneurs in investigations of corruption, risk of rationing of water and energy, and competitiveness problems. This caused high rate of unemployment and many companies ended up not being supported in the market by the lack of demand and investment, that is, the market became more selective and the population became more rigorous in the choice of services and products, mainly in the real estate market, where investment values tend to be higher and there is high market competition. Evolution of the Brazilian GDP until 2017 is shown in Figure 1.

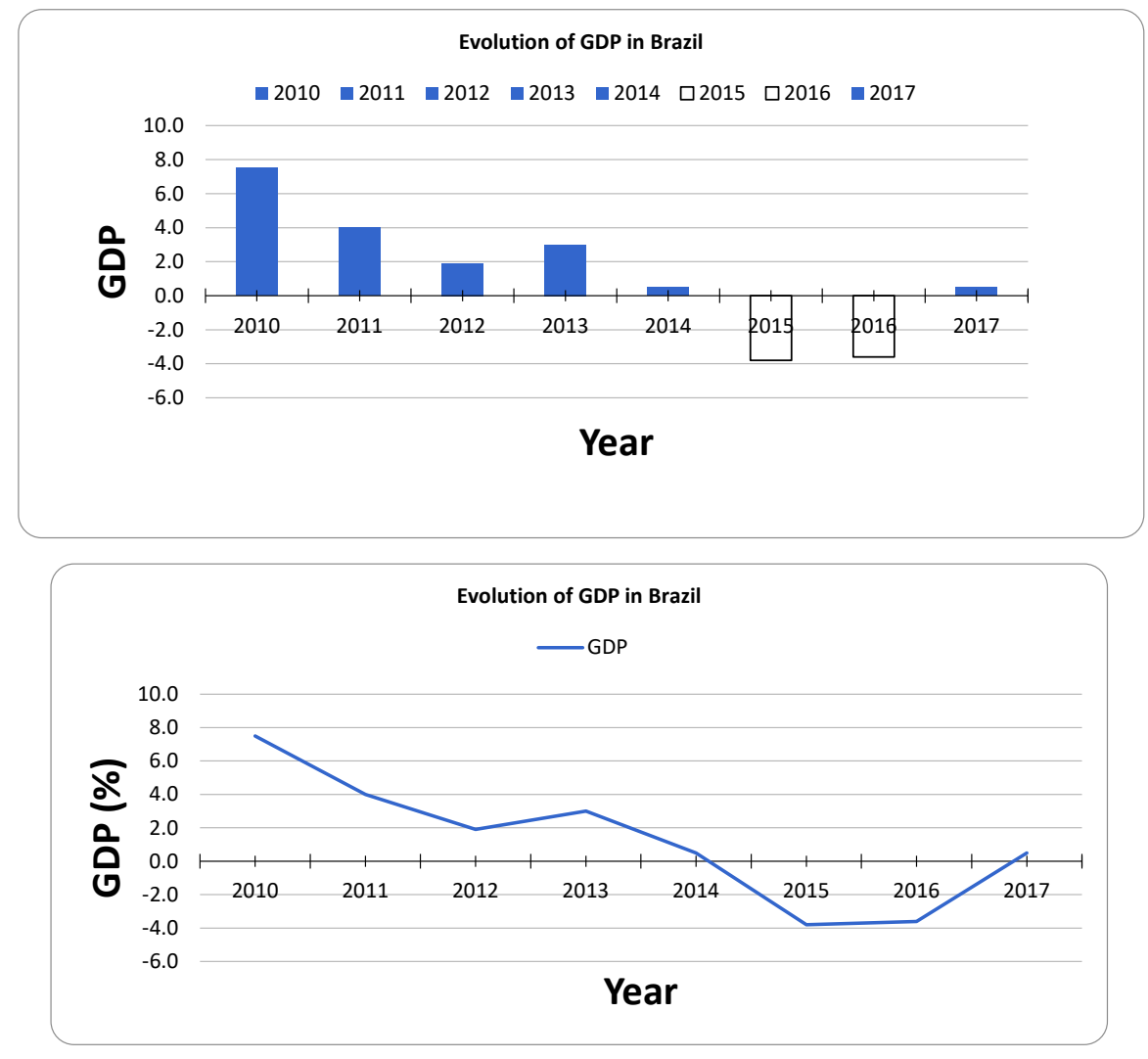

Fig. 1. Evolution of the Brazilian GDP until 2017 (Martello, 2017). 
As it can be seen in Figure 1, GDP declined dramatically in the years after the crisis of early 2014, but by 2017 there was a significant increase due to new government policies and spending cuts. This proposes a new era of the Brazilian market, which must be developed technologically, especially in the construction market, increasing investment in new environmental technologies that demonstrate potential, such as green roofs. Recife is one of the cities of the Northeast that has gradually developed in this area of construction, due to the appearance of new companies and industries in the region, generating new investments and opportunities.

\subsection{Heat Islands}

Another argument that has been of great importance considering the viability of green roofs is formation of islands of heat, extensive impermeable areas with little vegetal cover, generally caused by the accumulation of enterprises, sheds, extensive avenues, factories, high-rise buildings. The surface coating of the soil greatly influences the regional climate and air quality (Stone, 2004) and the Metropolitan Region of Recife has a large percentage of areas covered by concrete and asphalt, that is, surfaces capable of converting and storing incident solar radiation to a greater degree than vegetated areas. In addition, along with the population increase and economic development of the city, the buildings constructed in the last years have more and more floors, including on the edge of the beaches which prevents atmospheric circulation. Heat island growth dynamics in Recife can be observed in Figure 2.

Figure 2 demonstrates the gradual growth of heat islands. With the increase in population density, rural areas were eventually occupied by an urban area that increased over years, creating a domino effect that ended in the excessive increase of more than $70 \%$ in temperature.

Several studies have shown that green roofs can be very efficient in softening the interior temperature of a conventional building through thermal insulation, and it can be more than $6^{\circ} \mathrm{C}$ of the original temperature decrease, depending on the materials and factor of solar incidence, since the vegetation cover is responsible for dissipating or consuming the energy from the sun by evapotranspiration and photosynthesis, which will result in reducing the impacts already caused by heat islands. Energy impacts on specific buildings depend on individual factors, such as local climatic conditions, the type of roofing materials already used, and their useful life (Susca et al., 2011). Comparison of internal temperature in the construction with a conventional roof and another with a green roof is shown in Figure 3. 

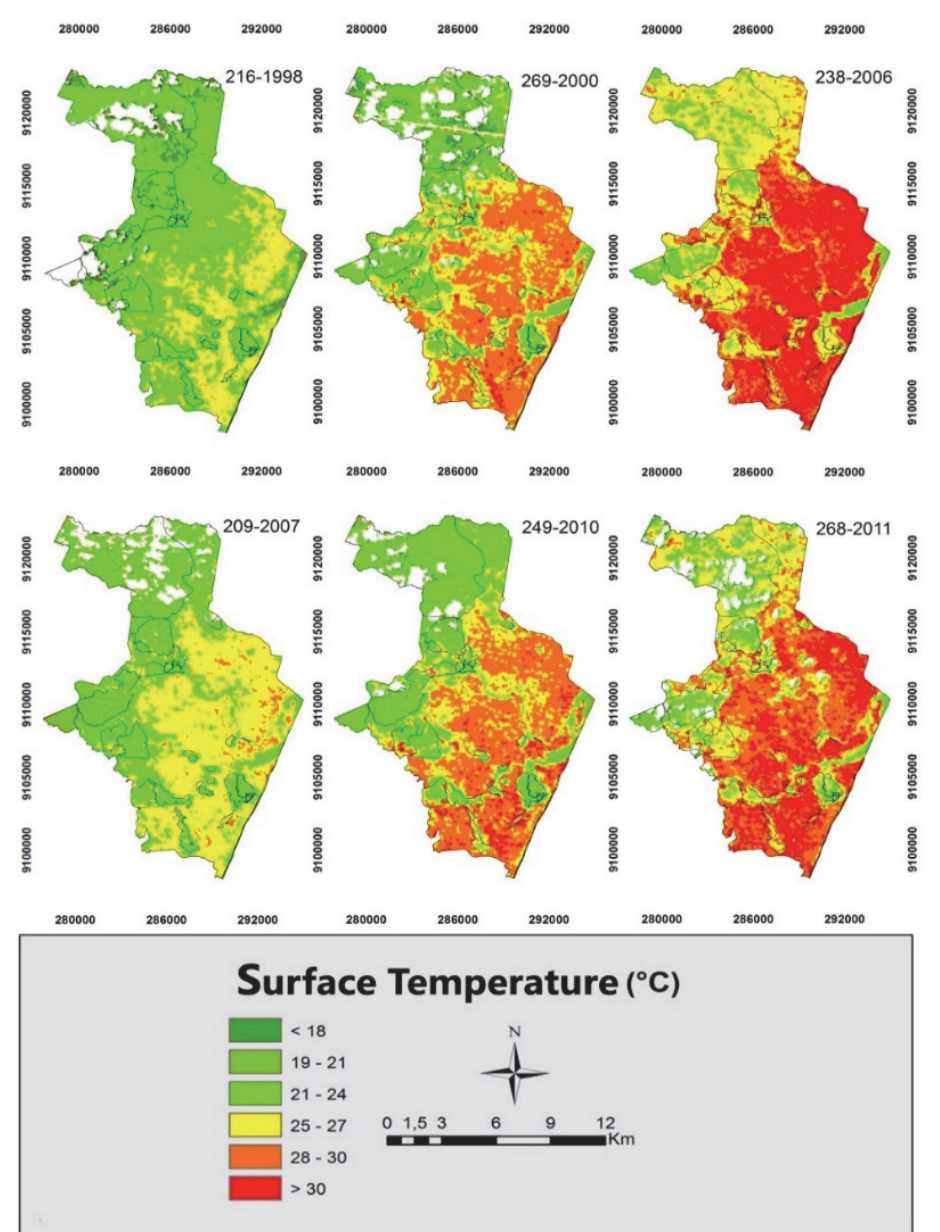

Fig. 2. Evolution of the heat islands of the metropolitan reef region by analyzing the spatial distribution of surface temperatures between 1998 and 2011.

(Moreira, 2014)

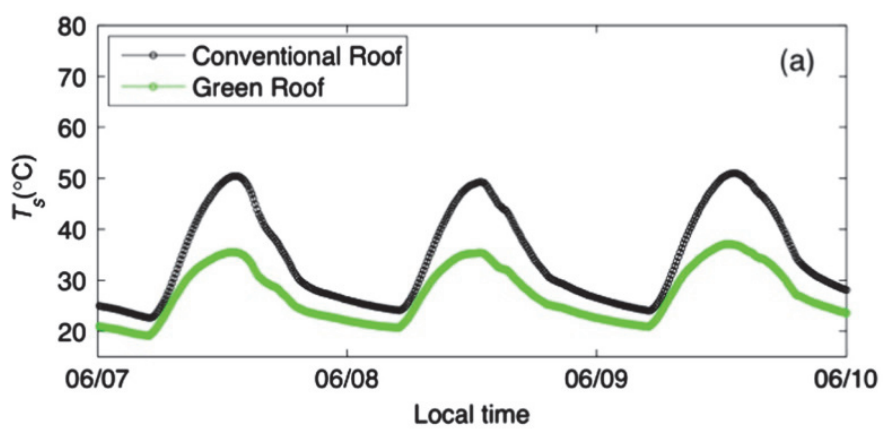

Fig. 3. Comparison of internal temperature in the construction with a conventional roof and another with a green roof (Li et al., 2014).

As it is seen in Figure 3, internal temperature in the construction with a conventional roof and another with a green roof has cyclical development tendencies. 


\subsection{Rainfall Index}

Recife even being a tropical city with high temperatures has a significant precipitation index, exceeding $2,000 \mathrm{~mm}$ per year, having heavy rains in all the seasons. In addition, a system of urban drainage is still precarious, which leads to flooding in the regions characterized by lower topography. This causes discomfort among residents by the impediment of locomotion and exposure of garbage left in the street. Figure 4 shows the average rainfall and temperature in Recife.

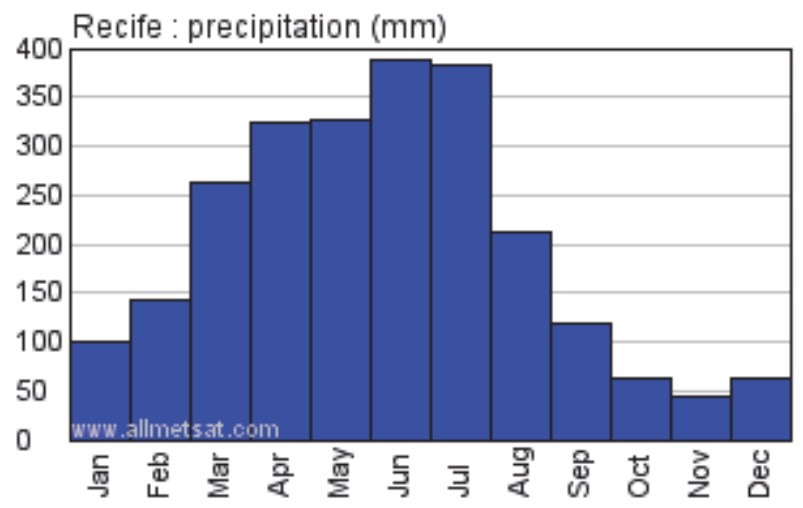

Fig. 4. Average rainfall and temperature in Recife (El Dorado Weather Inc., 2017).

As mentioned before, green roofs can be an option that on a large scale would help solve this problem by storing rain water, restoring the hydrological cycle that existed before the urbanization process, making it possible to save the cost of water used for non-potable purposes, chiefly in times of great summer heat.

\subsection{Reduction of Air Pollution}

According to the IPCC (Intergovernmental Panel on Climate Change) Recife is in $81^{\text {st }}$ place in the world ranking of cities vulnerable to the effects of climate change and $5^{\text {th }}$ of Brazil (Nicholls et al., 2008), because of the large amounts of $\mathrm{CO}_{2}$ emission, that contributes to the environmental imbalance that helps generate extreme climatic phenomena such as heavy rains that have been causing disruption in the Metropolitan Region due to the absence of a good rainwater drainage plan. According to the latest research done by the Secretariat of Sustainable Development and Environment of Recife completed in 2016, which comprises the data for 2014 and $2015,3,175,075 \mathrm{tCO}_{2} \mathrm{e}$ (tons of $\mathrm{CO}_{2}$ equivalent) were issued in 2014 and 2,908, $384 \mathrm{tCO} 2 \mathrm{e}$ in 2015 , which indicates a reduction of $266,691 \mathrm{tCO}_{2} \mathrm{e}$, corresponding to $8 \%$. The figure includes not only carbon dioxide but also other greenhouse gases converted into $\mathrm{CO}_{2}$, the main causes being land transport, air transport and landfills.

Much research has been published on the ability of plants to reduce pollutant effects, but little research has been done on the specific effect of green roofs. However, green roofs are a good choice to use in urban areas to complement 
existing vegetation that has been removed and improve product quality when installed in sufficient quantities (Currie \& Bass, 2008). It is estimated that $2000 \mathrm{~m}^{2}$ of uncut grass cover on a green roof can remove up to $4000 \mathrm{~kg}$ of $\mathrm{CO}_{2}$ (Johnson \& Newton, 2004).

\subsection{Price Comparisons with Current Products in the Real Estate Market}

Many factors affect cost-benefit analysis of installing green roofs, and the effectiveness of each factor depends on a variety of criteria such as climate, current economic circumstances, governmental and environmental policies, which are the most important (Berardi et al., 2014). The economic viability of green roofs is influenced by several factors and types of systems adopted in green roofs, for example, the type of vegetation most suitable for the climate and flora of the region. Extending the life of the waterproofing layers through the application of green roofs is often sufficient to ensure the economic viability of green roofs. In some cases, the waterproofing layer of a normal roof lasts for about 10 to 20 years, whereas green roofs can come to guarantee up to more than 50 years (Saiz et al., 2006).

In Brazil, a study was carried out in Curitiba by Savi making a direct comparison between different types of hedges most widely used in the markets. In this way, it was possible to verify cost variation and consider the systems associated with lower and higher construction costs. Cost comparison of coverage systems is shown in Figure 5.

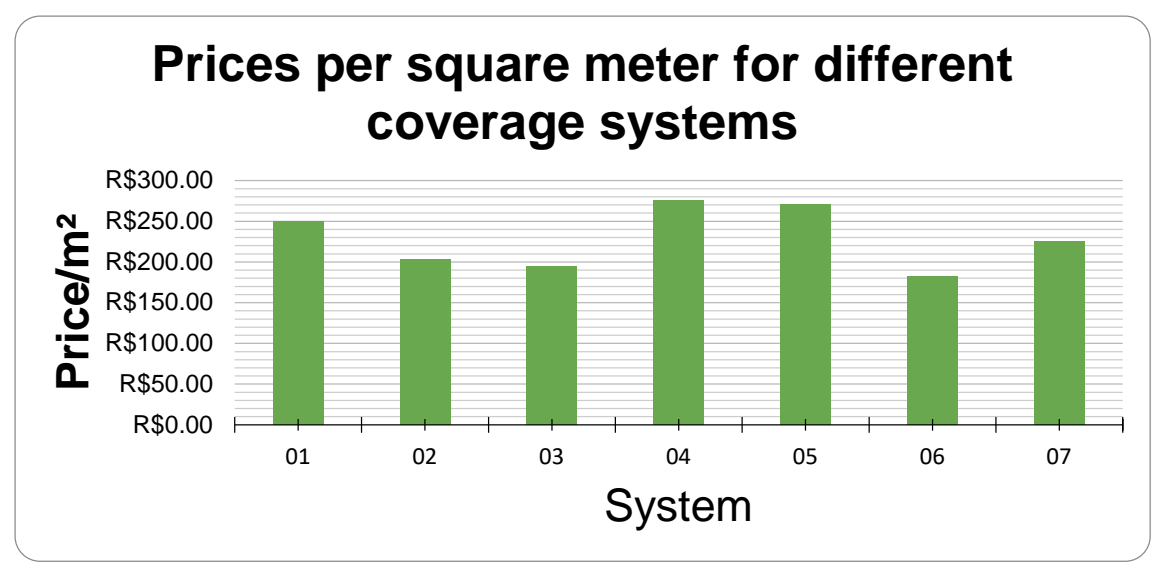

*- R means Brazil Real (the official Brazil currency)

Fig. 5. Cost comparison of coverage systems (Savi, 2012).

Figure 5 shows the prices per square meter of the following roofing systems: Pre-molded slab with ceramic tile (1); Pre-molded slab with shading (2); Roof covered with ceramic tile and finish in wood lining 3); Green roof of Hexa System (4); Modular system (5); Vernacular system (6), and Vernacular green roof on precast slab (7). Compared to other more commonly used roof systems, the green roof is obviously more expensive because it is a complementary and complex system that requires a greater technical knowledge. Therefore, to analyze the cost 
benefit, it is necessary to carefully analyze the design of materials used and the vegetation adopted and to understand the final objectives of the consumer, since it depends on the need for thermal insulation and available resources.

Having conducted the analysis, the authors summarize that the analyzed system has the following positive aspects and strengths:

- Drainage: Green roof vegetation helps drain rainwater, thus reducing the need for water and sewage systems to drain;

- Acoustic and Thermal Insulation: The vegetation is also able to reduce urban noise and reduce the temperature of the environment. This benefit, besides keeping the place more pleasant, still saves energy, as it decreases the use of air conditioners and air conditioning;

- Aesthetics: Green roof locations have a much more elegant and refined appearance;

- Valorization of the Property: The properties with green roofs tend to be more valued in the market, due to the benefits that they bring;

- Sustainable Action: This action contributes to the society, since it brings vegetation to urban environments, making numerous improvements in our day to day activities.

At the same time, the following weaknesses have been identified:

- Maintenance: The green roof needs frequent maintenance to keep its structure healthy and beautiful;

- High Initial Investment: The initial project can be very costly;

- Restrictions: Vegetation has several restrictions with regard to structure, temperatures and other environmental characteristics that can make the project unfeasible;

- Complex System: A green roof project is complex and requires skilled labor as it involves manipulation with several aspects of a property;

- Emergence of Pests: If the green roof does not receive proper maintenance, urban pests can appear on the roof and its benefits become almost invalid.

The authors define possible threats as follows:

- Increasing competitiveness in the market due to recent high demand, asit is a technology with great publicity.

- Lack of skilled labor available, with chances of the need to redo the work due to the lack of necessary knowledge.

- High need for maintenance in most cases.

- Few environmental policies that regulate installation, maintenance and use of green roofs, with no specific limits on consumer rights.

However, the following opportunities can be mentioned:

- Improvement of the Brazilian economy, which directly influences the construction market.

- Large rainfall in the city, which allows installation of green roofs for water storage.

- Municipal Law 18,112 of January 12, 2015, article 1 that requires buildings with more than four floors to have a green area, increasing the possibility of more companies considering the installation of green roofs. 
- Many areas of heat in the city, which cause a greater need to seek a technology to lower temperatures inside the buildings.

Concluding, Brazilian construction market offers both positive aspects and opportunities, however difficulties and threats can be found as well. For successful entrepreneurship in this area all previously analyzed aspects should be taken into account.

\section{CONCLUSION}

A company in the current economic situation in Brazil must be careful in taking risk in the market. The green roof technology has a great chance of success due to the current demand caused by the law that obliges the builders to adopt this type of service in their projects due to the climatic problems of the city of Recife. However, the market is uncertain because of the problematic political situation in recent years.

Through external factor analysis, it is possible to observe that Recife has many advantages in this area of construction with sustainable thinking, since it is the city that allows the development of this technology of coverage systems and provides great advantages for the consumer and for the environment. As it is a city with many heat islands, the green roofs in the upper area of the buildings offer the reduction of internal temperatures, consequently causing greater thermal comfort to the residents. In addition, the city has high rainfall rates, which offers a great opportunity to take advantage of the water storage technology provided by the drainage systems of green roofs. The exacerbated water consumption caused by high temperatures during all seasons has been a major economic problem among residents of the city, since the price of non-potable water has been increasing over the years. Considering environmental factors, green roofs can be a good resource to reduce the city's $\mathrm{CO}_{2}$ levels. Despite several initiatives on environmental projects adopted by the city hall, the city still faces great problems because of the pollution caused by land transport, air transport and landfills. On the social side, biodiverse roofs can generate healthy food by creating a new line of organic food, as well as become a new source of saving for consumers who choose to earn income through the sale of this organic food.

Therefore, a green roofing company in Recife has a good chance of considerable economic success if it can make investment in a good specialized labour, use good quality materials, be adaptable to the needs of the project and vegetation adopted, and offer a good service ensuring regular maintenance in the current market.

\section{REFERENCES}

Amado, F. A. D. T. (2011). Direito Ambiental Esquematizado. São Paulo, 2011.

Asdrubali, F., Schiavoni, S., \& Horoshenkov, K. V. (2012). A Review of Sustainable Materials for Acoustic Applications. Building Acoustics, 19(4), 283-311. https://doi.org/10.1260/1351-010x.19.4.283

Berardi, U., GhaffarianHoseini, A., \& GhaffarianHoseini, A. (2014). State-of-the-art analysis of the environmental benefits of green roofs. Applied Energy, 115, 411-428. https://doi.org/10.1016/j.apenergy.2013.10.047 
Bianchini, F., \& Hewage, K. (2012). How "green" are the green roofs? Lifecycle analysis of green roof materials. Building and Environment, 48, 57-65. https://doi.org/10.1016/j.buildenv.2011.08.019

Carter, T., \& Jackson, C. R. (2007). Vegetated roofs for stormwater management at multiple spatial scales. Landscape and Urban Planning, 80(1-2), 84-94. https://doi.org/10.1016/j.landurbplan.2006.06.005

Currie, B. A., \& Bass, B. (2008). Estimates of air pollution mitigation with green plants and green roofs using the UFORE model. Urban Ecosystems, 11(4), 409-422. https://doi.org/10.1007/s11252-008-0054-y

El Dorado Weather Inc. (2017). Recife, Pernambuco, Brazil Annual Climate with monthly and yearly average temperature, precipitation \& Sunshine Graphs. Retrieved May 2, 2017, from http://www.eldoradocountyweather.com/climate/brazil/Recife,\%20Pernambuco.html

Fioretti, R., Palla, A., Lanza, L. G., \& Principi, P. (2010). Green roof energy and water related performance in the Mediterranean climate. Building and Environment, 45(8), 1890-1904. https://doi.org/10.1016/j.buildenv.2010.03.001

Garcia-Estringana, P., Alonso-Blázquez, N., \& Alegre, J. (2010). Water storage capacity, stemflow and water funneling in Mediterranean shrubs. Journal of Hydrology, 389(3-4), 363-372. https://doi.org/10.1016/j.jhydrol.2010.06.017

Johnson, J., Newton, J. (2004). Building Green, a Guide for Using Plants on Roofs and Pavement. London: The London Ecology Unit.

Köhler, M., \& Keeley, M. (2005). The green roof tradition in Germany: The example of Berlin. In L. Hoffman, W. McDonough (Eds.). Green Roofs: Ecological Design and Construction. (pp. 108-112). New York: Schiffer.

Köhler, M. (2003). Plant survival research and biodiversity: Lessons from Europe. Paper presented at the First Annual Greening Rooftops for Sustainable Communities Conference, Awards and Trade Show; 20-30, Chicago.

Li, D., Bou-Zeid, E., \& Oppenheimer, M. (2014). The effectiveness of cool and green roofs as urban heat island mitigation strategies. Environmental Research Letters, 9(5), 055002. https://doi.org/10.1088/1748-9326/9/5/055002

Martello, A. (2017). Governo reduz de 1\% para 0,5\% projeção de alta do PIB em 2017 [Government reduces from $1 \%$ to $0.5 \%$ GDP as ahigh projection in 2017]. G1. Retrived September 15, 2017, from https://g1.globo.com/economia/noticia/governo-reduz-de-1-para-05-projecao-de-alta-dopib-em-2017.ghtml

Moreira, E. (2014). Balanço de energia e evapotranspiração na cidade do Recife-PE por sensoriamento remoto. Tese (Doutorado) - Departamento de Ciências Geográficas, Universidade Federal de Pernambuco (UFPE).

Nicholls, R. J., Hanson, S., Herweijer, C., Patmore, N., Hallegatte, S., Corfee-Morlot, J., Château, J., \& Muir-Wood, R. (2008). Ranking port cities with high exposure and vulnerability to climate extremes: exposure estimates. OECD Environment Working Paper No. 1. Organisation for Economic Co-operation and Development, Paris.

Palla, A., Sansalone, J. J., Gnecco, I., \& Lanza, L. G. (2011). Storm water infiltration in a monitored green roof for hydrologic restoration. Water Science \& Technology, 64(3), 766-773. https://doi.org/10.2166/wst.2011.171

RECIFE. Municipal Law No. 18,112 of January 12, 2015.

Rocha, S. (2016). Instituto cidade jardim. Retrieved October 4, 2017, from http://institutocidadejardim.com.br/2016/09/13/um-telhado-verde-nao-faz-verao-2-os-numerosdo-mercado-de-telhados-verdes-no-mundo/

Saiz, S., Kennedy, C., Bass, B., \& Pressnail, K. (2006). Comparative Life Cycle Assessment of Standard and Green Roofs. Environmental Science \& Technology, 40(13), 4312-4316. https://doi.org/10.1021/es0517522

Savi, A. C. (2012). Telhados Verdes: Análise Comparativa de Custo com Sistemas Tradicionais de Cobertura. Monografia (Sustainable Constructions) - Universidade Tecnológica Federal do Paraná. Curitiba, 125 p. 
Sharman, L. (2014). City of Sidney: Green Roofs and Walls Policy Implementation Plan. Retrieved May 2, 2017, from http://www.cityofsydney.nsw.gov.au/vision/towards-2030/sustainability/ greening-the-city/green-roofs-and-walls

Stone, B. (2004). Paving over paradise: how land use regulations promote residential imperviousness. Landscape and Urban Planning, 69(1), 101-113. https://doi.org/10.1016/j.landurbplan.2003.10.028

Susca, T., Gaffin, S. R., \& Dell'Osso, G. R. (2011). Positive effects of vegetation: Urban heat island and green roofs. Environmental Pollution, 159(8-9), 2119-2126. https://doi.org/10.1016/j.envpol.2011.03.007

Van Renterghem, T., \& Botteldooren, D. (2011). In-situ measurements of sound propagating over extensive green roofs. Building and Environment, 46(3), 729-738. https://doi.org/10.1016/j.buildenv.2010.10.006

Weng, Q., Lu, D., \& Schubring, J. (2004). Estimation of land surface temperature-vegetation abundance relationship for urban heat island studies. Remote Sensing of Environment, 89(4), 467-483. https://doi.org/10.1016/j.rse.2003.11.005

Wong, N. H., Cheong, D. K. W., Yan, H., Soh, J., Ong, C. L., \& Sia, A. (2003). The effects of rooftop garden on energy consumption of a commercial building in Singapore. Energy and Buildings, 35(4), 353-364. https://doi.org/10.1016/S0378-7788(02)00108-1

\section{AUTHORS' SHORT BIOGRAPHIES}

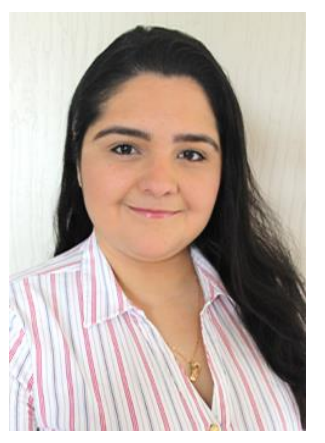

Ana Letícia B. F. Lemos is graduating in Civil Engineering from the Federal Rural University of Pernambuco, in addition to attending a Technologist in Building Construction Program at the same university. In the second half of 2016 until the first half of 2017, she obtained a scholarship from the EuroBrazilian Windows + project to participate in an exchange during graduation at Riga Technical University, Latvia. She was previously Vice President of the Academic Directory of the Civil Engineering course at the university from 2015 until 2016. She has already developed university projects in the fields of sustainable technologies such as Biodigesters and Green Roofs Development. She is interested in sustainable research such as green buildings, reuse of solid waste in buildings, bioconcrete, environmental management, ecological houses, cost reduction in civil engineering and maintenance through sustainable construction.

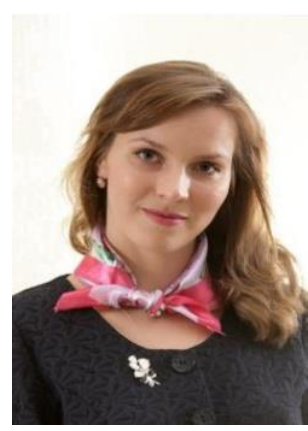

Linda Kauškale, Mg. oec., is a lecturer, a $\mathrm{PhD}$ student and an assistant researcher of the Institute of Civil Engineering and Real Estate Economics, Faculty of Engineering Economics and Management, Riga Technical University. She with distinction obtained Professional Master Degree in Civil Construction and Real Estate Management, has the qualification of Real Estate Economist and extensive practical experience.

She has participated in international scientific conferences and seminars in Latvia, Germany, United Arab Emirates, Singapore, Malaysia, Lithuania, etc. Her main research areas are sustainable real estate market concept, sustainable cities and sustainable construction, green buildings, macroeconomic analysis, business cycle, decision-making, environmental development, etc. She is a Professional Member of Industrial Engineering and Operations Management Society. In autumn 2016, she was Deutsche Bundesstiftung Umwelt (German Environmental Foundation) Scholarship holder. In autumn 2013, she was a FIABCI scholar. ORCID iD: http://orcid.org/0000-0002-0280-2977 